\title{
WATER REQUIREMENTS FOR THE NILE MAIZE CROP USING A LASER BEAM
}

\author{
G. A. Bakeer ${ }^{1} \quad$ H. E. Hassan ${ }^{2}$
}

\begin{abstract}
The aim of this research is to study the optimal time for irrigation, estimate water requirements of maize using visible laser and calculate water use efficiency to irrigate Nile maize crop. The experimental and field setups were carried out at the Institute of Laser Enhanced Science (NILES) and Farm of the Faculty of Agriculture, Cairo University, Giza, Egypt. Maize crop (11 hybrid variety) was used in the planting during autumn season of 2012, under the furrow and drip irrigation systems. Also two water regimes used soil moisture depletion (S.M.D) and evapotranspiration of crop (ETc) with three levels of water (10,25 and 50\% for S.M.D and 1.25, 1 and 0.75 for Etc). In the meantime the ETc was calculated using CROPWAT program. The experimental setup of laser beam transmission (LBT) measures transmission light through maize leaves considering the moisture content in the canopy leaf for different plants. The obtained results were as follows: 1) The values of laser beam transmission increased by decreasing of the SMD to the best time to irrigate according to use of LBT within range between 30 to 35 $m V$ at water regimes $10 \%$ of SMD and 1.25 ETc, 2) The crop water use efficiency (CWUE) was 1.40 and $1.66 \mathrm{~kg} / \mathrm{m}^{3}$ under furrow and drip irrigation systems with fully irrigation regimes, while, the traditional methods of furrow irrigation gave low CWUE ( $\left.1.0 \mathrm{~kg} / \mathrm{m}^{3}\right)$, and 3) The crop yield increased 856.70 and $531.57 \mathrm{~kg} / \mathrm{fed}$, with water saving of 167 and $40 \mathrm{~m}^{3} / \mathrm{fed}$ for drip and furrow irrigation systems at 10\% SMD respectively, compared with traditional furrow method.
\end{abstract}

1- Prof. Agric. Eng., Fac. of Agric., Cairo University

2- Assoc. Prof., Nat. Inst. of Laser Enhanced Sc. (NILES), Cairo, Univ., Egypt. 


\section{INTRODUCTION}

$\mathbf{W}$ askom (1994) reported that to maximize water productivity and avoid waste or water quality impacts, producers should determine; 1) When irrigation water should be applied; 2) How much water is needed to satisfy crop requirements?; 3) Application rate, set time, stream size, or set size required to apply the correct amount of water; and 4) Potential for agricultural chemicals to move from the target site due to irrigation practices.

George et al. (2002) reported that irrigation scheduling involves two questions, when (frequency) and how much (quantity) to irrigate a crop. Quantitative irrigation scheduling methods are based on three approaches, namely, crop monitoring, soil monitoring and water balance technique.

Schuerger et al. (2003) summarized that healthy and stressed plants were measured with two hyper spectral imagers, laser -induced fluorescence spectroscopy (LIFS), and laser-induced fluorescence imaging (LIFI) systems, if the four handheld remote sensing instruments were equally capable of detecting plant stress and measuring canopy chlorophyll levels in bahia grass. However unique capabilities of LIFS and LIFI instruments continue to argue for the development of laserinduced fluorescence remote sensing technologies.

Sander and Wim (2004) found that the measured average of Crop Water Productivity (CWP) per unit water depletion was $1.80 \mathrm{~kg} \mathrm{~m}^{-3}$ for maize. The range of CWP is very large and lays between $1.1-2.7 \mathrm{~kg} \mathrm{~m}^{-3}$ for maize crop. They also showed that the variability of CWP could be ascribed to: (i) climate; (ii) irrigation water management and (iii) soil (nutrient) management, among others.

Francisco et al. (2004) stated that the canopy temperature differences between plants and a well-watered control about $1,2,3,4$ and $5 \pm 0.5^{\circ} \mathrm{c}$ were tested. Plants irrigated when their canopy temperature was $3 \pm 0.5^{\circ} \mathrm{c}$ above the control had their relative growth rate mean value increased up to $59.7 \%$, yielding $2,260.2 \mathrm{~kg} \mathrm{ha}^{-1}$, with a reduction of $38.0 \%$ in the amount of water used. Plants irrigated when their canopy temperature was $4 \pm 0.5^{\circ} \mathrm{c}$ yielded $1,907.6 \mathrm{~kg} \mathrm{ha}^{-1}$. 
Oweis et al. (2005) revealed that water use efficiency (WUE), was known as water productivity, was determined as the ratio of crop yield per unit area, in terms of grain or total aboveground dry matter (biomass), to crop evapotranspired (mm). WUE is usually expressed either in $\mathrm{kg} / \mathrm{ha} \mathrm{mm}$ or in $\mathrm{kg} / \mathrm{m}^{3}$ ( $\mathrm{kg}$ of grain or biomass per unit of consumed or evapotranspired Water).

Saito et al. (2006) stated that the Broad of laser-induced fluorescence (LIF) spectrum $400 \mathrm{~nm}$ to $800 \mathrm{~nm}$ gave information about pigments inside the leaves. Plant leaves can emit fluorescence in response to laser irradiation which is called laser-induced fluorescence (LIF). Therefore, LIF will be a good indicator to monitor plant status. LIF spectrum of a poplar's green leaf representative LIF spectrum with two peaks at 685 and $740 \mathrm{~nm}$ and small ones at 460 and $530 \mathrm{~nm}$ are observed.

Webber et al. (2006) mentioned that increasing (WUE), which was defined as amount of plant material produced per unit of water transpired, is way for arid and semi-arid areas to increase their agricultural production where there is little or no prospect for expansion of water resources.

According to Shock (2007) growers irrigation using one of several criteria; (1) intuition; (2) calendar days since the last rainfall or irrigation; (3) crop evapotranspiration ; (4) soil water monitoring.

Javaid and Khalid (2009) said that the total evapotranspiration of maize was $451 \mathrm{~mm}$ for the whole growing season. The highest grain yield i.e. $2993 \mathrm{~kg} /$ ha of maize was obtained from $\mathrm{T}_{2}$ treatment and lowest i.e.1993 $\mathrm{kg} / \mathrm{ha}$ was obtained when farmer's practices (To) were followed. All irrigations were applied before soil reached to the desired MAD. The application efficiency ranged between 50-81. The average application efficiency of $70 \%$ was obtained with treatment $T_{1}$ i.e. (0.5 Epan). The yield per unit volume of irrigation water applied is most significant measure for evaluating the judicious use of water. The average water use efficiency of maize ranged from 0.7 to $1.8 \mathrm{~kg} / \mathrm{m}^{3}$.

Edward (2009) reported that the infrared readings will often measure soil temperature when canopy cover is sparse. These readings usually result in higher temperature readings since the soil tends to heat up quickly. The improvement of on-farm irrigation systems and the 
introduction of low cost water saving irrigation technologies have been identified as key components of reducing agricultural water demand.

Masoud and Ghodratolah (2010) mentioned that for increasing water use efficiency in corn (Zea mays L.) crop at different planting densities and decrease water wastes in usual methods of surface irrigation. Three irrigation methods include: conventional furrow irrigation (CFI), fixed every other furrow irrigation (FFI) and alternate every other furrow irrigation (AFI) and three different plant densities (7, 8 and 9 plant $\mathrm{mG} 2$ ) were used. The results showed that there were no difference between both FFI and AFI, but the performance of them decreased irrigated water at the rates of $26.2 \%$ and $23 \%$, respectively comparing with control and then yield at the rates of $11 \%$ and $13.6 \%$, respectively.

Yang (2012) concluded that it is possible to implement deficit irrigation strategies for reducing agricultural water consumption by increasing the interval between irrigations during the periods other than around flowering.

Hirich et al. (2012) indicated that under deficit irrigation during vegetative growth stage of maize applying $75 \%$ of ETm lead to increasing of $19.4 \%$ in terms of fresh ear yield, $9.4 \%$ in terms of dry grain yield, $10.5 \%$ in terms of number of ears per plant, $11.5 \%$ for the 1000 grains weight and $19 \%$ in terms of crop water productivity compared with fully irrigated treatment. Meanwhile, those parameters in addition to root, shoot and plant height, have been affected by deficit irrigation during vegetative growth stage when increasing water stress degree more than $50 \%$ of ETm.

The objectives of this study were : 1) Determine optimal time for irrigation, 2) Estimate water requirements of autumn maize crop using visible laser, and 3) Calculate water use efficiency to irrigate autumn maize crop.

\section{MATERIAL AND METHODS}

The present investigation was conducted at the farm of the Faculty of Agriculture, Cairo University, Giza, Egypt. The carried experiments aimed at studying the possibility of scheduling irrigation for maize crop using laser technology, compared to ordinary method for managing irrigation water application. 


\section{The experiments of field}

The cultivated area of maize crop was 0.5 feddan $\left(2100 \mathrm{~m}^{2}\right)$ divided into three plots. Each plot consists of 82 rows- $70 \mathrm{~cm}$ apart and $12 \mathrm{~m}$ in length with buffer zone between plots. Two irrigation systems (furrow and drip) and controlled water applied were used. The traditional modified surface irrigation system was used as a control using gated pipe. Irrigation regimes were based on soil moisture depletion (SMD) and consumptive use (WCU) calculations. Maize kernels (11 hybrid variety) were planted at spacing of $25 \mathrm{~cm}$ within row in autumn season (from 15 August to 15 November), on the year 2012. All the agronomic practices were applied as commonly used according to the recommendation of the Ministry of Agriculture.

\section{Irrigation systems:}

Water source: is a well of $50 \mathrm{~m}$ depth and water static head of $3 \mathrm{~m}$

Pump: The pump used was an electrical centrifugal pump. Its discharge reached $20 \mathrm{~m}^{3} / \mathrm{h}$ at 3 bar pressure head with $2 / 2$ inch inlet/outlet diameter.

Control head: control head consisted of screen filters $2 / 2$ inch inlet / outlet, $20 \mathrm{~m}^{3} / \mathrm{h}$ discharges and 120 meshes with pressure gauge before the filter. Venture was used for fertigation, with commutative meter $2 / 2$ inch outlet diameter, and air vent vacuum relief valve, 2 inch.

Main and sub main lines: main line was PVC pipe of $90 \mathrm{~mm}$ in diameter, with up to $6 \mathrm{~atm}$ pressure, $24 \mathrm{~m}$ length and sub main line is PVC pipe of $63 \mathrm{~mm}$ diameter, up to 6 atm pressure. Manifold was PVC pipe of $50 \mathrm{~mm}$ diameter, with up to 6 atm pressure for drip irrigation and manifold of 3 inch for surface irrigation methods.

\section{Plots representing the irrigation systems:}

1- Furrow Irrigation (F). This system consisted of riser with valve of 3 inch and a gated pipe orifice of 1 inch used to irrigate each furrow.

2- Surface Drip Irrigation (SD). Lateral in each plot consisted of riser with valve and pressure gauge. Drip lines of $16 \mathrm{~mm}$ diameter (with builtin emitters), $30 \mathrm{~cm}$ emitter distance, and emitter discharge $\mathrm{L} \mathrm{hr}^{-1}$, and the discharge calibration indicated that actual average discharge was 4.15 $\mathrm{Lhr}^{-1}$.

3- Conventional irrigation (control treatment): to represent the traditional furrow irrigation system. 


\section{Irrigation regimes:}

\section{Soil moisture depletion (SMD)}

Three irrigation application regimes were used as water applied when the soil moisture depletion (SMD) was reached 10\%, 25\% and 50\%. Irrigation water was applied to reach field capacity at all levels. Soil moisture sensor, based on Time Domain Refractometery (TDR) theory, was used to control water level in the soil.

\section{Consumptive use (CU)}

The CROPWAT software program was used to calculate $\mathrm{ET}_{\mathrm{c}}$ values for maize crop under the experimental condition. The CROPWAT is a decision support system by the land and Water Development Division of FAO (1995) based on the use of calculating reference evapotranspiration $\left(\mathrm{ET}_{\mathrm{o}}\right)$ it uses Penman Monteith equation. The $\mathrm{ET}_{\mathrm{c}}$ is calculated within the program using coefficient ( $\mathrm{k}_{\mathrm{c}}$ value according to Allent et al., 1998).

The data indicate the values of crop and irrigation water requirements calculated using CROPWAT program. The obtained values of crop water requirements are found to be $423 \mathrm{~mm}, 338 \mathrm{~mm}$ and 254 for three levels of irrigation regimes, $1.25,1.00$ and 0.75 from $\mathrm{ET}_{\mathrm{c}}$, respectively.

\section{Soil and Water Analysis}

The soil samples were collected from three soil depths (0-15, 15-30, and $30-45 \mathrm{~cm}$ ) before cultivation and harvesting to determine the physical and chemical characteristics of the experimental soil site.

\section{Soil physical analysis:}

Soil mechanical analysis was carried out using pipette method, using NH $\mathrm{OH}$ as dispersing agent and soil bulk density of soil was determined using the undisturbed soil cores according to methods described by Klute (1986), as shown in Table (1).

Field capacity (FC) and permanent wilting point (PWP) were determined using the pressure cooker and pressure membrane apparatus. A saturated undisturbed and disturbed soil samples were equilibrated at suction pressures of 0.33 and 15.0 bar, respectively, according to Shawky (1976), and the values of the available water (AW) were calculated as the difference between the (FC) and (PWP). 
Table 1: Some soil physical characteristics of the investigated soil layers.

\begin{tabular}{|c|c|c|c|c|c|c|}
\hline \multirow{2}{*}{$\begin{array}{c}\text { Soil } \\
\text { depth } \\
\text { (cm) }\end{array}$} & \multicolumn{4}{|c|}{ Particle size distribution (\%) } & \multirow{2}{*}{$\begin{array}{c}\text { Texture } \\
\text { class }\end{array}$} & \multirow{2}{*}{$\begin{array}{c}\text { Soil bulk } \\
\text { density } \\
\mathrm{kg} / \mathrm{m}^{3}\end{array}$} \\
\hline & $\begin{array}{c}\text { Coarse } \\
\text { sand } \\
\end{array}$ & Fine sand & Silt & Clay & & \\
\hline $0-15$ & 1.63 & 33.89 & 30.97 & 31.89 & Clay loam & 1118 \\
\hline $15-30$ & 1.68 & 33.71 & 30.78 & 31.74 & Clay loam & 1245 \\
\hline $30-45$ & 0.17 & 43.23 & 26.81 & 28.93 & Clay loam & 1395 \\
\hline
\end{tabular}

\section{Soil chemical analysis}

Total soluble salts, soil reaction $(\mathrm{pH})$, and soluble cations and anions (extract $1: 2.5$ ) and total calcium carbonate were determined according to Page (1982), as shown in Table (2).

Table 2: Some soil chemical characteristics of the investigated soil layers.

\begin{tabular}{|c|c|c|c|c|c|c||c|c|c||}
\hline \multirow{2}{*}{$\begin{array}{c}\text { Soil } \\
\text { depth } \\
(\mathrm{cm})\end{array}$} & \multirow{2}{*}{$\mathrm{pH}^{*}$} & \multirow{2}{*}{$\begin{array}{c}\mathrm{EC}_{\mathrm{e}}{ }^{*} \\
\mathrm{dS} . \mathrm{m}^{-1}\end{array}$} & \multicolumn{3}{|c||}{ Soluble cations (meq/L) } & \multicolumn{3}{|c|}{$\begin{array}{c}\text { Soluble anions } \\
\text { (meq/L) }\end{array}$} \\
\cline { 5 - 10 } & & & $\mathrm{Na}^{+}$ & $\mathrm{K}^{+}$ & $\mathrm{Ca}^{++}$ & $\mathrm{Mg}^{++}$ & $\mathrm{Cl}^{-}$ & $\begin{array}{c}\mathrm{CO}_{3}^{+} \\
+ \\
\mathrm{HCO}_{3}{ }^{-}\end{array}$ & $\mathrm{SO}_{4}{ }^{-}$ \\
\hline $0-15$ & 7.46 & 1.56 & 5.19 & 0.41 & 4.92 & 5.96 & 4.39 & 11.93 & 0.10 \\
$15-30$ & 7.62 & 2.51 & 4.32 & 0.28 & 8.43 & 13.29 & 7.28 & 9.43 & 9.60 \\
$30-45$ & 7.53 & 1.78 & 4.07 & 0.26 & 6.89 & 7.27 & 8.95 & 1.45 & 8.10 \\
\hline
\end{tabular}

* in soil paste extract

\section{Chemical analysis of irrigation water}

Water reaction $(\mathrm{pH})$, electric conductivity $(\mathrm{EC})$, and soluble cations and anions were determined according to Page (1982), as shown in Table (3).

Table 3: Some chemical analysis of irrigation water.

\begin{tabular}{|c|c|c|c|c|c|c|c|c|c|c|}
\hline \multirow{2}{*}{$\mathrm{pH}$} & \multicolumn{2}{|c|}{$\mathrm{EC}$} & \multicolumn{3}{|c|}{ Soluble cations (meq/L) } & \multicolumn{3}{|c|}{ Soluble anions (meq/L) } & \multirow{2}{*}{ SAR } \\
\cline { 2 - 10 } & $\mathrm{PPm}$ & $\mathrm{dSm}^{-1}$ & $\mathrm{Ca}^{++}$ & $\mathrm{Mg}^{++}$ & $\mathrm{Na}^{+}$ & $\mathrm{K}^{+}$ & $\begin{array}{c}\mathrm{CO}_{3}^{+} \\
\mathrm{HCO}_{3}^{-}\end{array}$ & $\mathrm{SO}^{=}$ & $\mathrm{Cl}^{-}$ & SAR \\
\hline 7.15 & 530.80 & 0.79 & 3.50 & 2.40 & 0.80 & 0.16 & 4.00 & 1.24 & 1.00 & 0.50 \\
\hline
\end{tabular}




\section{Time Domain Refractometery (TDR)}

TDR measures the volumetric moisture percentage based on theory of applying the frequency of time domain refractometery (TDR) technique to determine soil moisture contents in different soil layers for soil moisture depletion (SMD) treatments in drip and furrow irrigation systems (Kaffka et al., 1997; Iles and Dosmann, 1999).

\section{The setup of laser beam transmission (LBT) device}

The experimental setup (Fig. 1) was developed and assembled in the laboratory of laser applications in agricultural applications, National Institute of Laser Enhanced Science (NILES), Cairo University and consists of laser source, holders, photovoltaic avometer and woody base: to measure laser beam transmission through maize leaf.

Diode laser: The diod laser specification (table 4) (Semi conductor laser type) with wavelength from $600-700 \mathrm{~nm}$ (visible laser) was used in the present work as light source. The diode laser was sitting on parallel holder on woody base by plastic holder.

Table 4: The specifications of diode laser.

\begin{tabular}{|l|l|}
\hline Item & Diode laser \\
\hline Source of manufacture & USA \\
\hline Model & Laser max, inc \\
\hline Type & Semiconductor \\
\hline Wavelengths, $\mathrm{nm}$ & $600-700 \mathrm{~nm}$ \\
\hline Beam & Continuous wave \\
\hline Output power, $\mathrm{mW}$ & $\leq 4.25 \mathrm{~mW}$ \\
\hline Beam diameter, $\mathrm{mm}$ & 1 \\
\hline Beam divergence, $\mathrm{mrad}$ & 0.62 \\
\hline Polarization ratio & Random \\
\hline Class & III a laser product \\
\hline
\end{tabular}

Holders: The plastic holders were used to fix diode laser and photovoltaic parallel on woody base. Plastic holders with diameter 50 $\mathrm{mm}$ was parallel and fixed on woody base by screw blot. 

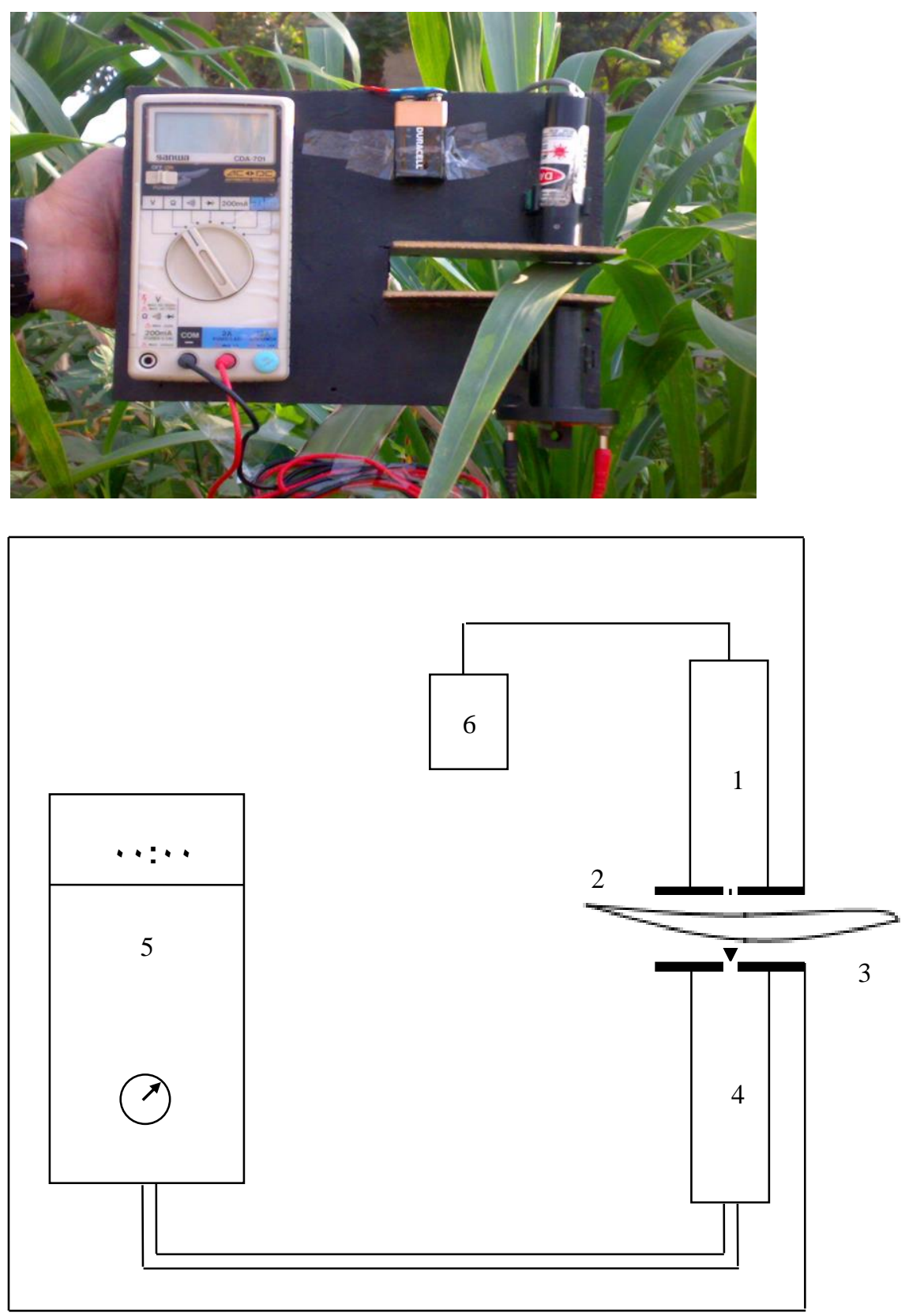

1 Diode laser.

$4 \quad$ Photovoltaic cell.

2 Laser beam.

5 Avometer.

3 Maize leaf.

6 Power supply

Fig. 1: Assembled setup of laser beam transmission (LBT) device. 
Photovoltaic cell: Photovoltaic cell was fixed on a woody base by plastic holder and its efficiency was about $30 \%$. It converted light beam into electrical signals transferred to an avometer from maize leaf.

Avometer: Avometer was used to measure the electrical signals as volt resulting from converting the transmission of light through maize leaf by a photovoltaic cell. The light intensity transmission through maize leaf passes to the photovoltaic cell. The avometer has the following specifications as shown in table (5).

Table 5: The specifications of the AVO meter.

\begin{tabular}{|l|l|}
\hline \multicolumn{1}{|c|}{ Item } & \multicolumn{1}{c|}{ Specification } \\
\hline Model & Digital, 1 millimeter mod. CDA-701 \\
\hline Source of manufacture & Japan \\
\hline Accuracy & $0.1 \mathrm{mV}(\mathrm{DC})$ \\
\hline Range & $1 \mathrm{mV}$ to $1000 \mathrm{~V}$ \\
\hline Limit of error & $\pm(0.6 \%$ rged + dgt $)$ \\
\hline
\end{tabular}

\section{Scheduling of irrigation}

Procedure to manage the irrigation water was applied as follows:

\section{Laser beam transmission (LBT)}

The intensity of transmission through maize leaves at different ages was calculated from the following equation with negligible light reflection because the laser beam was reflected on itself according to the low of conservation of energy (1):

$$
\mathrm{I}=\mathrm{T}+\mathrm{R}+\mathrm{A}
$$

Where: $\mathrm{I}=$ the incident beam, volt; $\mathrm{T}=$ transmission beam;

$\mathrm{R}=$ reflection; and $\mathrm{A}=$ absorption.

\section{Irrigation efficiency (Ei)}

Furrow irrigation system efficiency was computed, according to the method described by James (1988), and according to equations ( 2 and 3 ), also surface and subsurface drip irrigation systems were evaluated according to the method described by Merriam and Keller (1978).

$$
\begin{gathered}
E_{a}=\frac{R_{Z}}{d_{w}} \times 100 \\
R_{Z}=\frac{D\left(\theta f c-\theta_{i}\right)}{100}
\end{gathered}
$$

Where $: \mathrm{E}_{\mathrm{a}}=$ efficiency of application [\%]; 
$\mathrm{RZ}=$ amount of water stored in the root zone $[\mathrm{mm}]$;

$\mathrm{d}_{\mathrm{w}}=$ depth of water applied [mm];

$\mathrm{D}=$ depth of root zone $[\mathrm{mm}]$;

$\theta f c_{\text {_ }}$ and $\_\theta i=$ volumetric water contents in percent at field capacity and prior to irrigation, respectively.

\section{Irrigation water requirements and traditional methods}

According to Borham (2001), the depth of irrigation water requirements was calculated by using the following equation (4):

$$
\mathrm{I}=\frac{\left(\theta_{F C}-\theta_{v}\right) \times d_{s}+L_{f}}{E_{1}} \ldots \ldots-(4)
$$

Where:I = total depth of irrigation water requirements [mm/interval];

$\Theta_{F . C}=$ soil water content at Field Capacity on volume basis [\%];

$\Theta \mathrm{v}=$ percentages of soil moisture content at irrigation time on volume basis depending on the irrigation treatment (level of Soil Moisture Depletion)[\%];

$\mathrm{d}_{\mathrm{s}}=$ depth of soil layer $[\mathrm{mm}]$;

$\mathrm{L}_{\mathrm{f}}=$ leaching factor.

$\mathrm{E}_{\mathrm{i}}=$ irrigation efficiency.

\section{Yield and yield components}

At harvesting, two meter lengths for one row were chosen randomly from each plot and harvested to estimate the yield components as follows:

Number of plants, average mass (g), and total yield (ton/fed).

Water Use Efficiency (WUE)

Water use efficiency of crop was calculated according to Giriappa (1983) using the following equations (5 and 6:

$$
\begin{aligned}
& \text { CWUE }=\frac{\text { Yield }}{\text { ETa }} \ldots \ldots .-. \text { (5) } \\
& \text { IWUE }=\frac{\text { Yield }}{\text { IWRa }}-\ldots . .-(6)
\end{aligned}
$$

Where:

ETa $=$ actual evapotranspiration, $\left(\mathrm{m}^{3} \cdot \mathrm{fed}^{-1}\right)$

IWRa $=$ actual irrigation water requirement, $\left(\mathrm{m}^{3} \cdot \mathrm{fed}^{-1}\right)$

CWUE $=$ crop water use efficiency,

IWUE = irrigation water use efficiency, $\left(\mathrm{kg} \cdot \mathrm{m}^{-3}\right)$ 


\section{RESULTS AND DISCUSSIONS}

This study aims at using a new technique to determine when to irrigation and how much water to apply, (irrigation scheduling) for maize crop. To achieve the aim of this research; the simple and accurate application methods used the TDR to control the SMD and laser beam methods.

\section{Laser beam transmission (LBT)}

The laser beam transmission setup was used to measure the transmission through the leaf of maize.

\section{Furrow irrigation}

The data in figs. (2 and 3) represent the LBT for furrow irrigation under different regimes of SMD and ETc. The data indicate that the absorption of the laser beam is more than the transmission. The data also exhibited that the LBT were 41.4, 42.8 and $46 \mathrm{mV}$ for 10, 25 and 50\% SMD, respectively before irrigation. Meanwhile, they were 38.2, 38.6 and 40.6 $\mathrm{mV}$ at the same different SMD, respectively after irrigation. In the same time the LBT increased before irrigation than after irrigation. Also the data exhibited that the LBT under ET regimes is more than SMD, The LBT values were 51.8, 56.6 and $59.8 \mathrm{mV}$ for $1.25,1$ and $0.75 \mathrm{ET}$.

\section{Drip irrigation}

The data in figs. (4 and 5) represent the LBT under drip irrigation for different water regimes. Generally, they take the same trend for furrow irrigation. Dealing with water regimes, the LBT increased under deficit irrigation than full irrigation. Also the data exhibit the trend under high water regimes of $10 \%$ SMD and $1.25 \mathrm{ET}$, the difference in LBT is very small. But under low water regimes of 50\% SMD and $0.75 \mathrm{ET}$, but the LBT is more than high water regimes. This means that the LBT increased as the CWSI increased. Dealing with irrigation system the LBT under high regimes are the same. However, for low water regimes, the LBT increased under furrow irrigation than drip irrigation. Meanwhile, the LBT under ET regimes is more than SMD regimes.

It is clear that the LBT ranged from 40 to $42 \mathrm{mV}$ under high water regimes while the LBT ranged from 50 to $75 \mathrm{mV}$ under low water regimes. The LBT is the same for high water regimes with the furrow and drip irrigation while the LBT was different under two water regimes. 


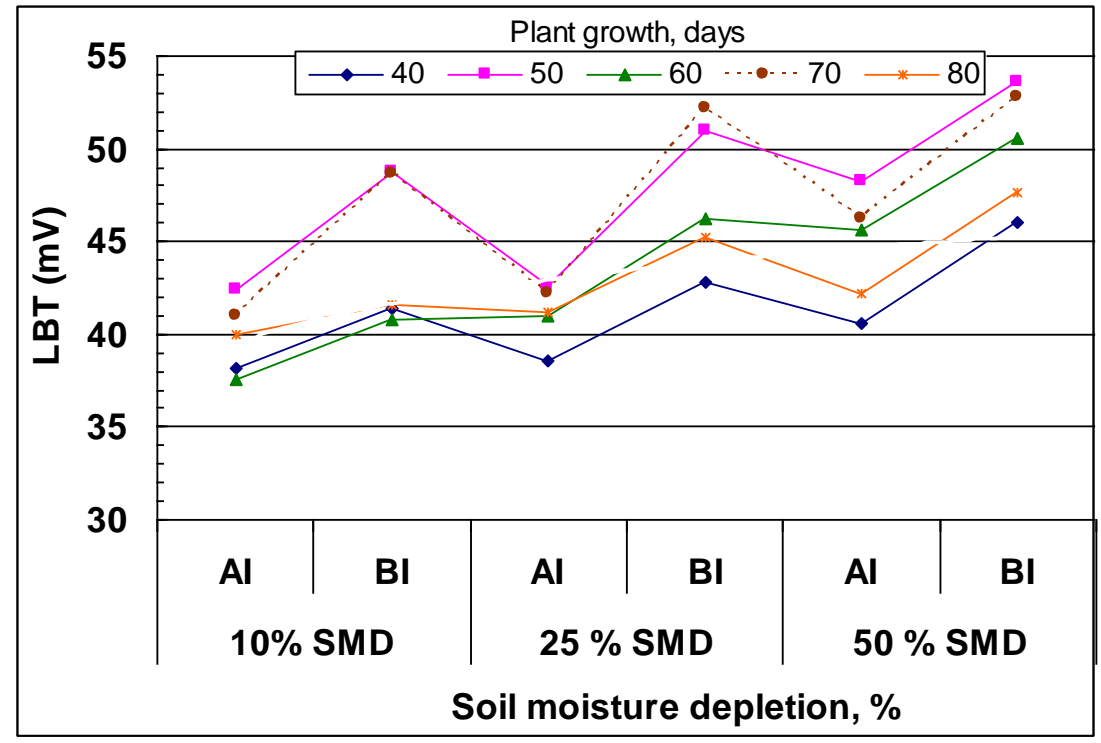

Fig. 2: Relationship between soil moisture depletion (SMD) and laser beam transmission (LBT) after and before irrigation at different plant growth stages under furrow irrigation.

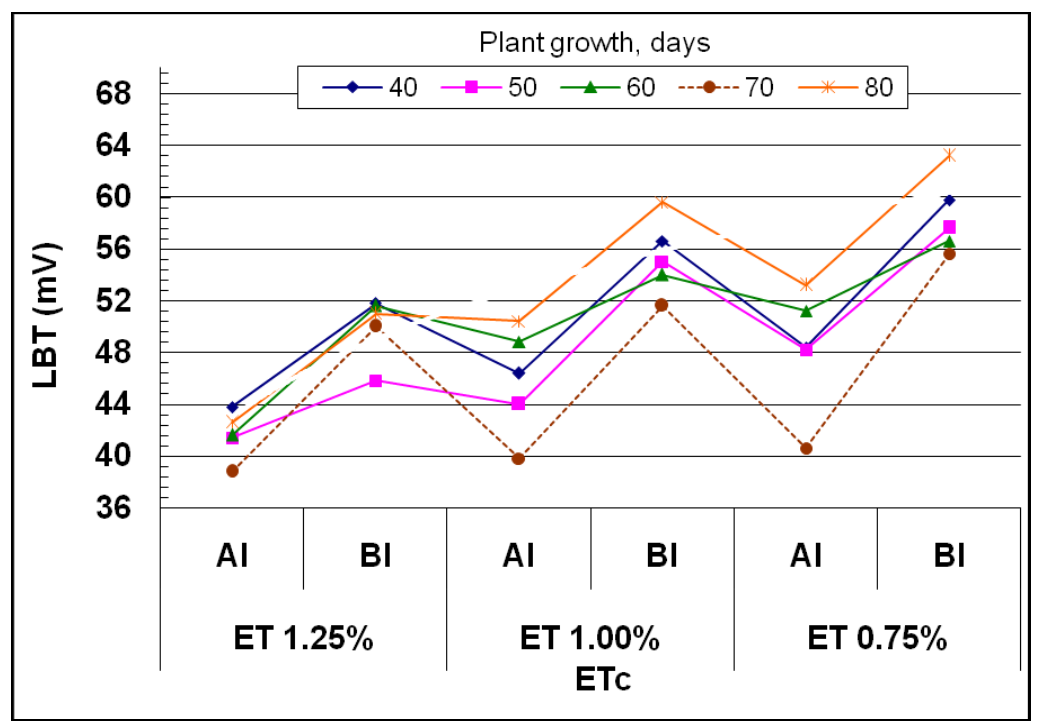

Fig. 3: Relationship between laser beam transmission (LBT) and crop evapotranspiration (ETc) after and before irrigation at different plant growth stages under furrow irrigation. 


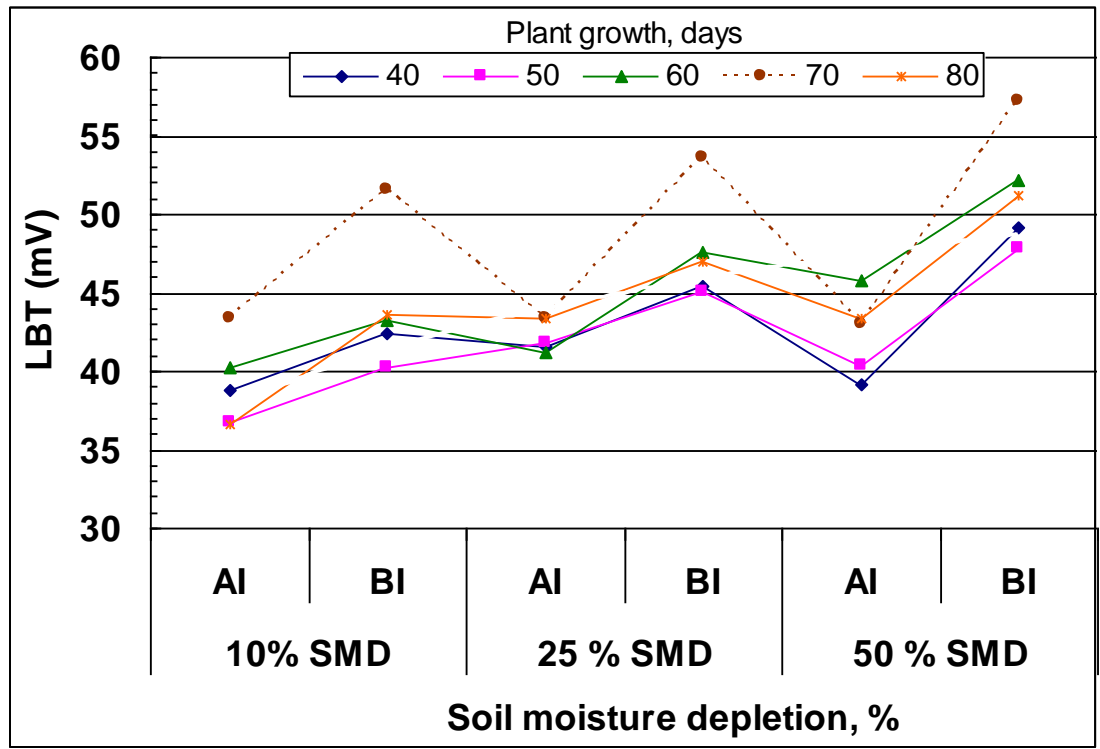

Fig. 4: Relationship between soil moisture depletion (SMD) and laser beam transmission (LBT) after and before irrigation at different plant growth stages under drip irrigation.

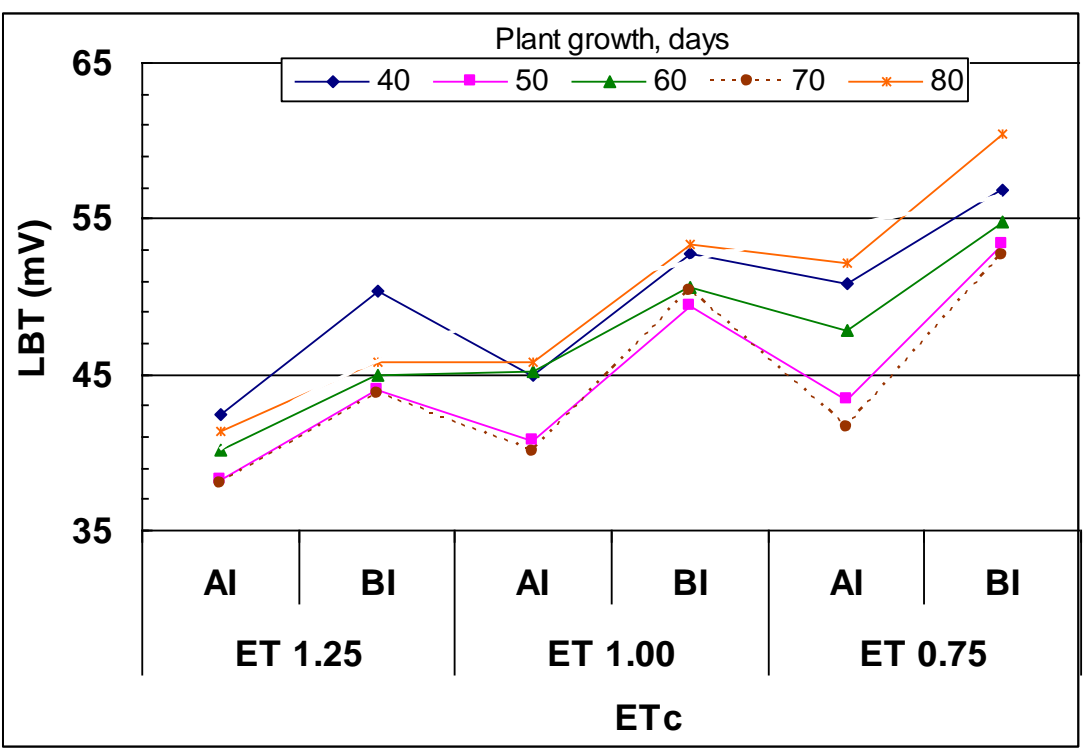

Fig. 5: Relationship between laser beam transmission (LBT) and crop transpiration (Etc) after and before irrigation at different plant growth stages under drip irrigation. 


\section{Comparison between SMC and LBT under furrow and drip irrigations:}

The figures $(6,7,8$ to 9) present the relationship between LBT and SMC for furrow and drip irrigation for different regimes. It is clear from the data that the LBT increased as SMC decreased. The LBT ranged from 42 to $48 \mathrm{mV}$ while the SMC ranged from 33 to $35 \%$ for SMD 10 under furrow irrigation. Meanwhile, the LBT ranged from 42 to $52 \mathrm{mV}$ when SMC ranged from 32 to $33 \%$. At same time, the LBT ranged from 48 to $55 \mathrm{mV}$ when SMD ranged from 25 to $31 \%$. Dealing with ETc regimens, the LBT were 52, 60, $65 \mathrm{mV}$ respectively. Dealing with drip irrigation system, the figures present the relationship between LBT and SMC for different regimes. The data take the same trend for furrow irrigation. But the LBT values for drip irrigation were less than far furrow irrigation, the LBT were 50, 53 and $58 \mathrm{mV}$ for 10, 25 and 50\% SMD.

Dealing with ET regimes under drip irrigation the LBT value is more than for SMD.

LBT and SMC were as follows:

1 -The Laser beam transmission increased as SMC decreased.

2 -The Laser beam transmission is less than absorption beam.

3 -The LBT ranged from 35 to $75 \mathrm{mV}$ is considered the best time for irrigation, and

4 -There is a good relationship between SMD and CWSI which affected the LBT. 

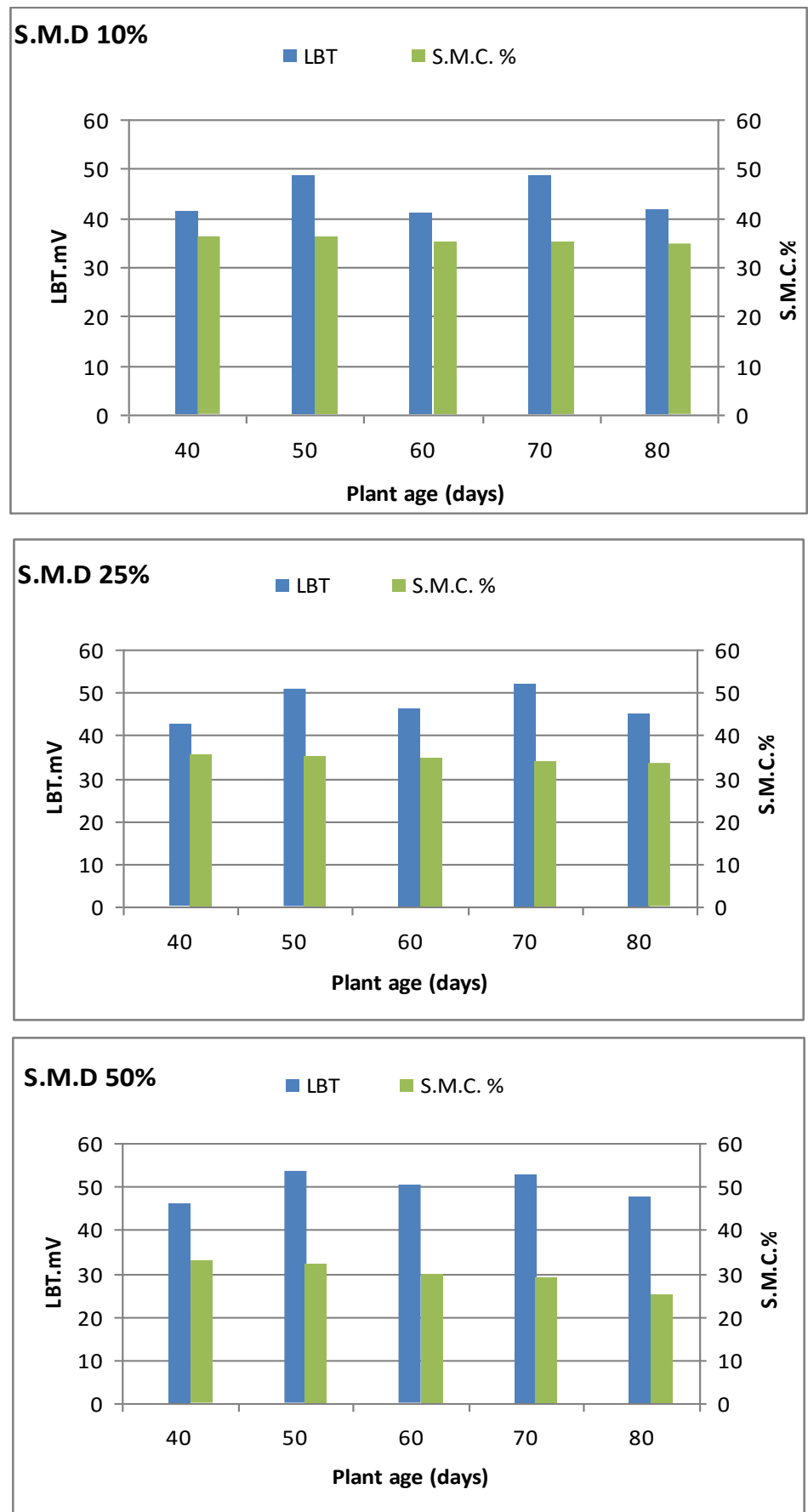

Fig. 6 : Relationship between laser beam transmission (LBT) and soil moisture content (SMC) at different soil moisture depletions (SMD) under furrow irrigation. 

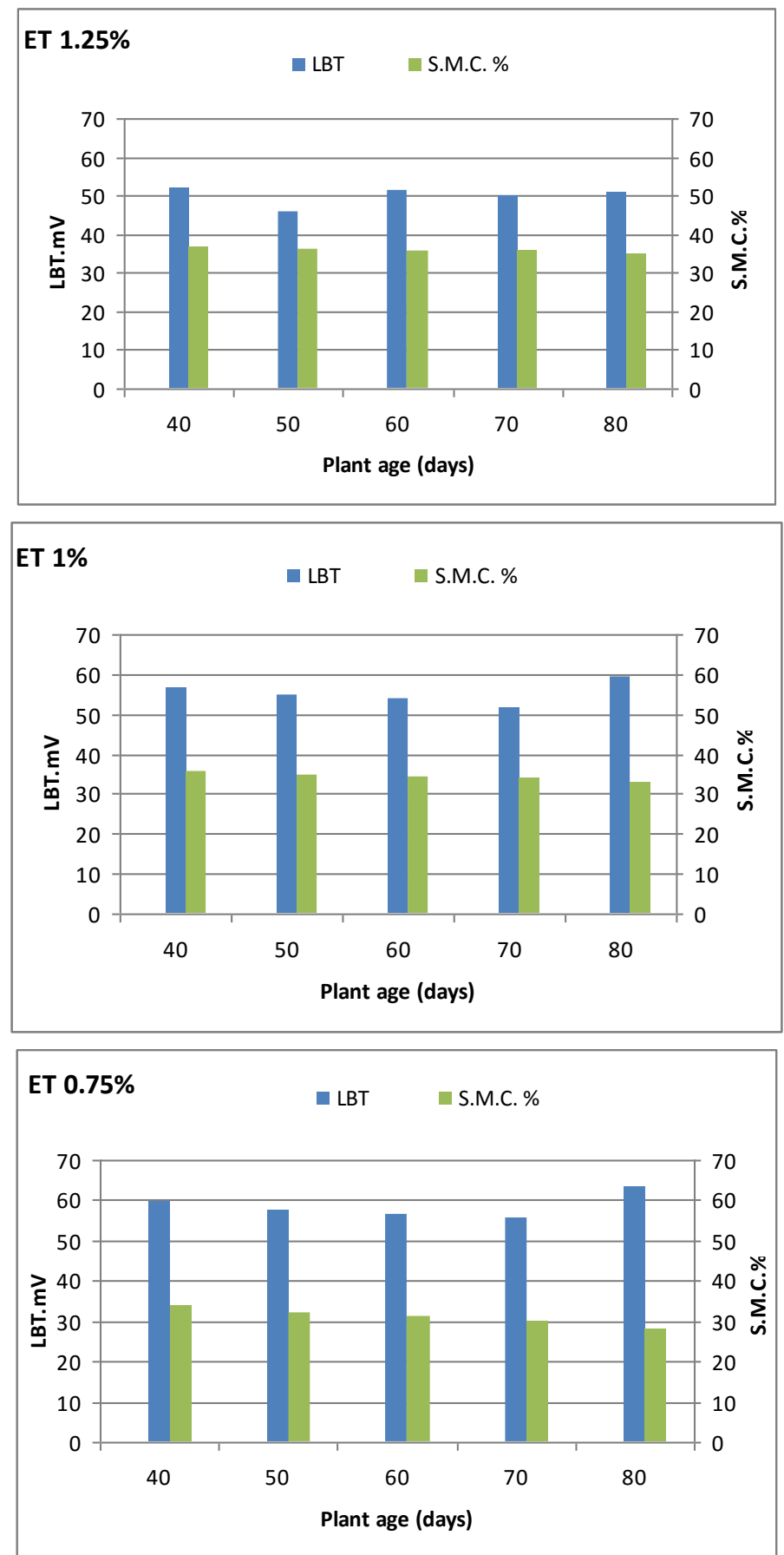

Fig. 7 : Relationship between laser beam transmission (LBT) and soil moisture content (SMC) at different crop evapotranspirations (Etc) under furrow irrigation. 

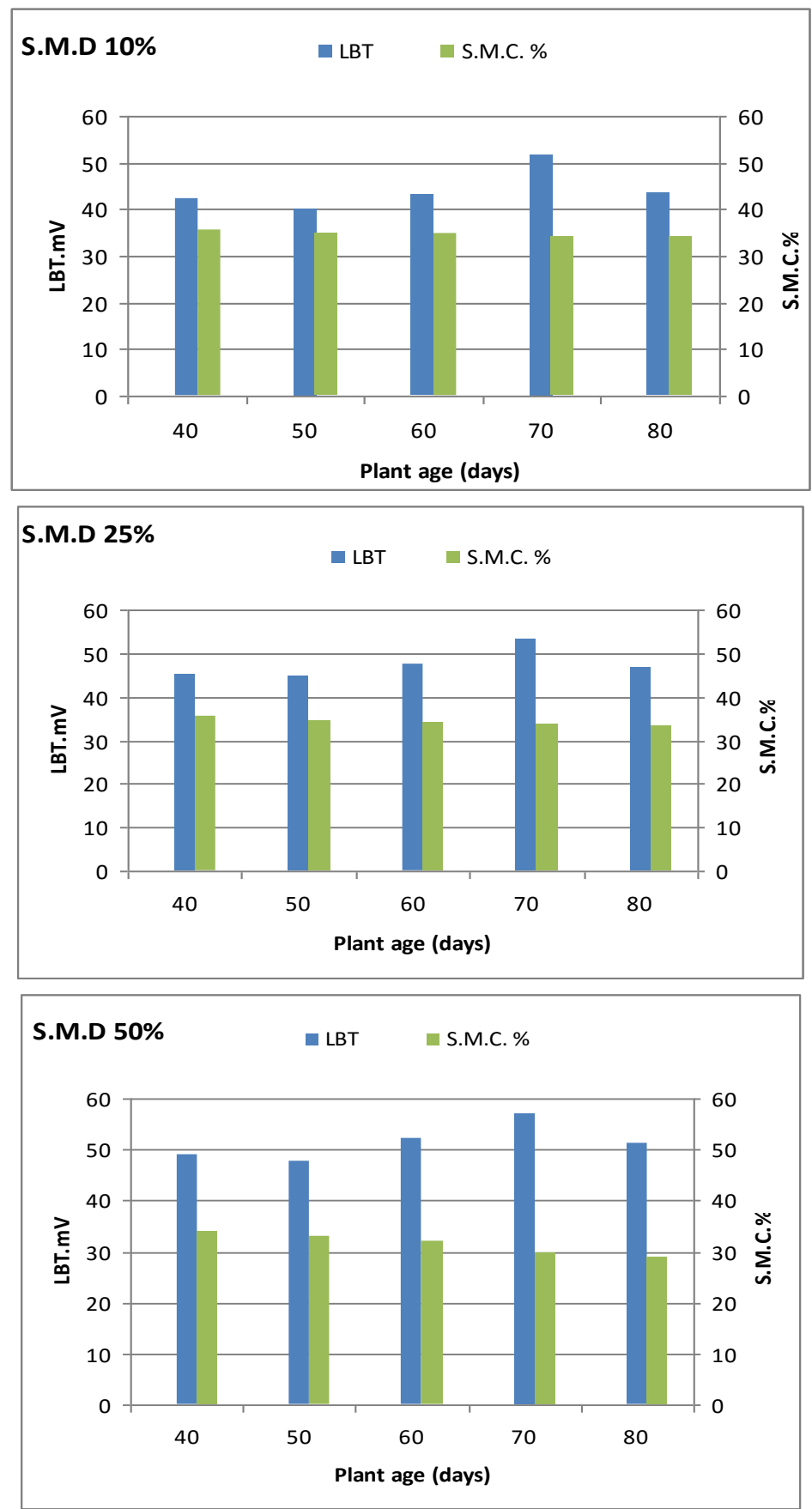

Fig. 8 : Relationship between laser beam transmission (LBT) and soil moisture content (SMC) at different soil moisture depletions (SMD) under drip irrigation. 

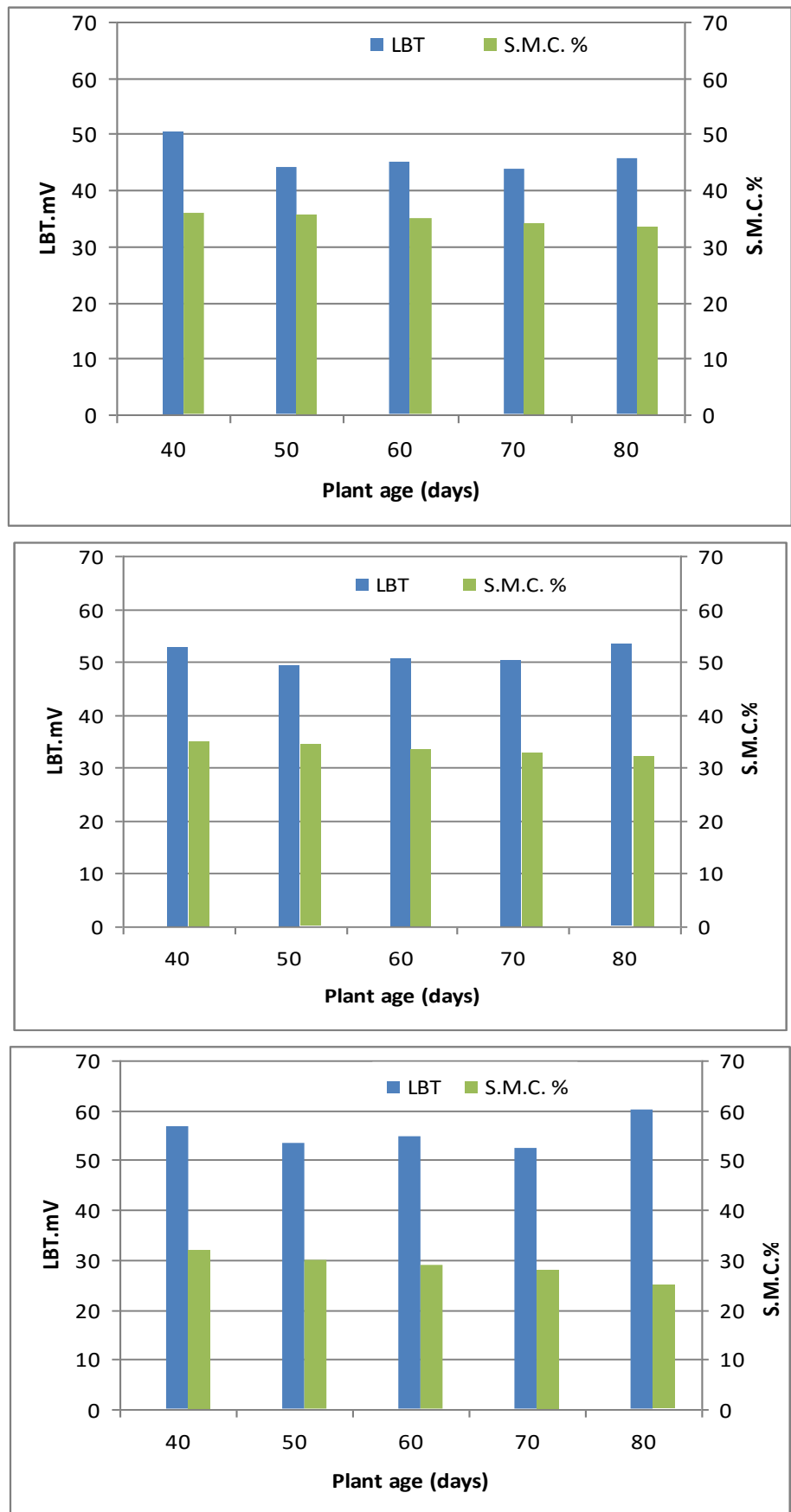

Fig. 9 : Relationship between Laser beam transmission (LBT) and soil moisture content (SMC) at different crop evapotranspirations (Etc) under drip irrigation. 


\section{Yield and crop water use efficiency:}

\section{Response of maize grain yield to irrigation regimes:}

Figs. (10 and 11) and Table (6) show that the mean values of grain yield were 2881.23, 2346.12and 1605.24 kg/fed for10, 25 and 50\% SMD, respectively, under furrow irrigation, while the mean values of grain yield were $2166.71,1968.60$ and $1332.50 \mathrm{~kg} /$ fed for $1.25,1$ and 0.75 Etc, respectively, under furrow irrigation.

At the same time, the mean values under drip irrigation were 3205.46, 2469.60 and $1605.73 \mathrm{~kg} /$ fed for 10, 25 and 50\% SMD, respectively, while the mean value were $2492.64,2005.35$ and $1476.80 \mathrm{~kg} /$ fed for $1.25,1$ and 0.75 ET, respectively.

From the data of grain yield it can be conclude that:

a- The high grain yield is with high water regimes of $10 \%$ and 1.25 ET.

b- The mean value of grain yield for drip irrigation is more than furrow irrigation.

c- The mean grain yield of 10, 25\% SMD and 1.25 ET is more than the traditional methods.

\section{Crop Water Use Efficiency (CWUE):}

Table (6) shows that the highest CWUE value was $1.66 \mathrm{~kg} / \mathrm{m}^{3}$ under drip irrigation with $10 \% \mathrm{SMD}$, while the highest CWUE under furrow irrigation was $1.40 \mathrm{~kg} / \mathrm{m}^{3}$ with $10 \%$ SMD, while the CWUE was 1.44 $\mathrm{kg} / \mathrm{m}^{3}$ for drip irrigation with $1.25 \mathrm{ETc}$. At the same time, the CWUE was $1.22 \mathrm{~kg} / \mathrm{m}^{3}$ under furrow irrigation, with $1.25 \mathrm{ET}$ water regimes. This may be due to the good control of water management and the low consumption of water. Dealing with irrigation regimes, the highest value of CWUE is obtained with $10 \%$ of SMD.

The highest value of CWUE is $1.66 \mathrm{~kg} / \mathrm{m}^{3}$ under drip irrigation system. This may be due to that this treatment gives higher grain weight, quite high in total yield $(856.70 \mathrm{~kg} / \mathrm{fed})$. At the same time, with water regimes of Etc, the highest value is with $1.25 \mathrm{ET}$, the value was $1.44 \mathrm{~kg}$ under drip irrigation system. This is maybe due to the low consumption of water compared to other treatments.

The crop yield increased 856.70 and $531.57 \mathrm{Kg} / \mathrm{fed}$, with save water 167 and $40 \mathrm{~m}^{3} / \mathrm{fed}$ for drip and furrow irrigation system at 10\% SMD respectively, compared with traditional furrow method. 


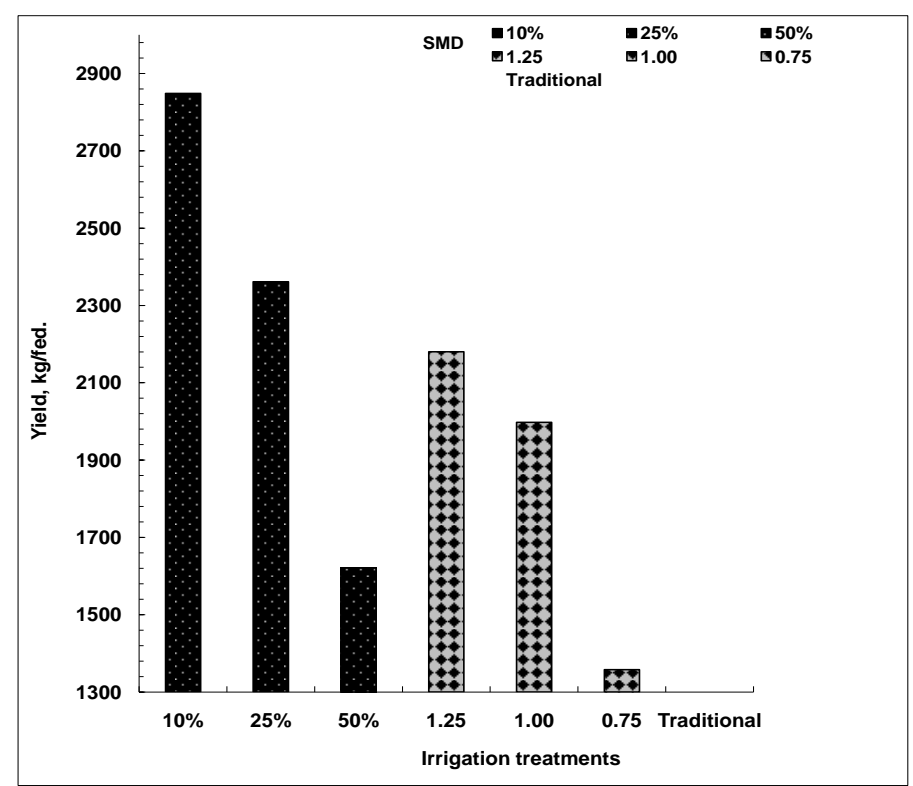

Fig. 10: Average maize production under different irrigation treatments with furrow irrigation.

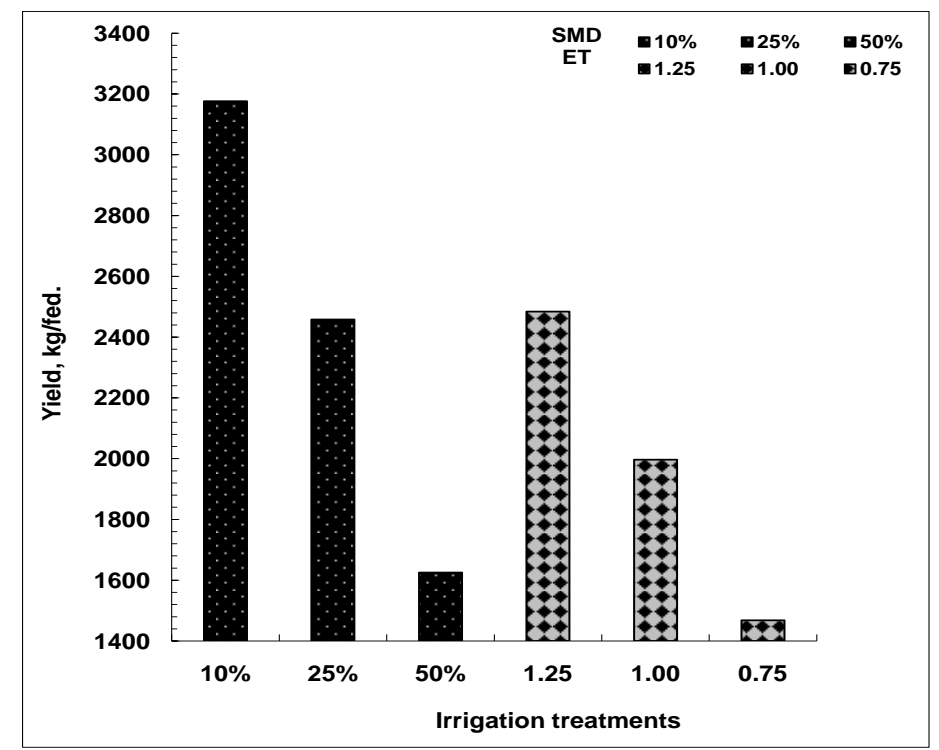

Fig. 11: Average maize production under different irrigation treatments with drip irrigation. 
Comparing the CWUE with different regimes, the value exhibited big differences from 1.66 to $1.13 \mathrm{~kg} / \mathrm{m}^{3}$ under drip irrigation for 10 and $50 \%$ SMD. Also, the CWUE ranged from 1.44 to $1.42 \mathrm{~kg}$ under 1.25 and 0.75 ET. This may be due to the non-stressed 10\% SMD and 1.25 ET and the stressed treatment 50\% SMD and 0.75 ET.

Table 6: Interaction between irrigation systems and water regimes (water stress) on yield and crop water use efficiency.

\begin{tabular}{|c|c|c|c|c|}
\hline $\begin{array}{l}\text { Irrigation } \\
\text { system }\end{array}$ & Treatments & $\begin{array}{c}\text { Yield } \\
\mathrm{kg} / \mathrm{fed}\end{array}$ & $\begin{array}{c}\text { Water apply } \\
\mathrm{m}^{3} / \text { fed }\end{array}$ & $\begin{array}{l}\text { CWUE, } \\
\mathrm{kg} / \mathrm{m}^{3}\end{array}$ \\
\hline \multirow{6}{*}{$\underset{:}{3}$} & SMD $10 \%$ & 2881.23 & 2058 & 1.40 \\
\hline & SMD $25 \%$ & 2346.12 & 1764 & 1.33 \\
\hline & SMD $50 \%$ & 1605.24 & 1638 & 0.98 \\
\hline & ET (1.25) & 2166.71 & 1776 & 1.22 \\
\hline & ET (1) & 1968.60 & 1419 & 1.40 \\
\hline & $\operatorname{ET}(0.75)$ & 1332.50 & 1065 & 1.25 \\
\hline \multirow{6}{*}{ 芯 } & SMD $10 \%$ & 3205.46 & 1931 & 1.66 \\
\hline & SMD $25 \%$ & 2469.60 & 1680 & 1.47 \\
\hline & SMD $50 \%$ & 1605.73 & 1421 & 1.13 \\
\hline & ET (1.25) & 2492.64 & 1731 & 1.44 \\
\hline & ET (1) & 2005.35 & 1383 & 1.45 \\
\hline & ET (0.75) & 1476.80 & 1040 & 1.42 \\
\hline \multicolumn{2}{|c|}{ Traditional furrow } & 2349.76 & 2098 & 1.12 \\
\hline
\end{tabular}

\section{CONCLUSIONS}

The obtained results were as follows:

1-The value of both the transmission and absorbed beam into the leaf of plant affected the value of the leaf moisture content, which is affected with soil moisture content

2-The values of laser beam transmission increased by decrease of the SMD so the best time to irrigate according to use of LBT is between 30 to $35 \mathrm{mV}$ at water regimes $10 \%$ of SMD and $1.25 \mathrm{ETc}$.

3-The crop water use efficiency (CWUE) was 1.40 and $1.66 \mathrm{~kg} / \mathrm{m}^{3}$ under furrow and drip irrigation systems with fully irrigation regimes, while, the traditional methods of furrow irrigation gave low CWUE. 
4-The crop yield increased 856.70 and $531.57 \mathrm{~kg} / \mathrm{fed}$, with water saving of 167 and $40 \mathrm{~m}^{3} /$ fed for drip and furrow irrigation systems at $10 \%$ SMD respectively, compared with traditional furrow method.

5- Laser technique can be used as a water management tool with acceptable accuracy.

\section{REFERENCES}

Allen, R.G.; Pereira, L.S; Raes, D. and Smith, M., (1998). Crop evapotranspiration: guidelines for computing crop water requirement. FAO Irrigation and Drainage Paper no. 56, Rome, Italy.: 341-347.

Borham, T. (2001). Studies on water requirements for some crops under different cropping system. Dep. of Soil Sci.. Fac. of Agric., Cairo Univ. M.Sc.: 115-120.

Edward, C. M. (2009) Methods of Measuring for Irrigation Scheduling - when" Arizona Water Series No.30, Arizona Univ., Coll. Ag. and Life Sci. : 89-93

FAO (1995). Glossary of land and water terms. Land and Water Dev. Div. Citedin: $184-189$.

Francisco, A. L., A. O. Marco, R. Morethson, F. L. Nei and M. Moacyr (2004) " Infrared thermometry to schedule irrigation of common bean" Pesq. agropec. bras., Brasília, 9 (2):113-121.

George, B.A., B.R.S. Reddy, N.S. Raghuwanshi and W.W. Wallender (2002). Decision support system for estimating reference evapotranspiration. J. Irrig. Drain. Eng. 128 (1): 1-10.

Giriappa, S. (1983). Water use efficiency in agriculture, agricultural development and rural transformation unit. Inst. for Social and Ec. Change Bangalore. Oxford and IBH, New Delhi.:151 -157.

Hirich A., A. Rami, K. Laajaj, R. Choukr-Allah, S. E. Jacobsen, L. El youssfi and H. El Omari (2012). Sweet corn water productivity under several deficit irrigation regimes applied during vegetative 
growth stage using treated wastewater as water irrigation source. World Acad. of Sci., Eng. and Tech. 61 : 840-847.

Iles, J. K. and M. S. Dosmann (1999). Effect of organic and mineral mulches on soil properties and growth of red maple. Hort. Sci. 33(3): 449.

James, L. G. (1988). Principles of farm irrigation systems design., Washington St. Univ.: 127-134.

Javaid, A. T. and U. Khalid (2009) Regulated deficit irrigation scheduling of maize crop. Dep. of Water Manag., NWFP Agr. Uni., Peshawar, Pakistan. Sarhad J. Agric. 25 (3) 441-450.

Kaffka, S., K. Hembree, G. Peterson and D. Daxue. (1997). Sugarbeet seeds emerged well under moderately saline conditions. Dep. of Agron. and Range Sci. Univ. of California.", Davis, USA.:414-419.

Klute, E. A. (1986). Methods of soil analysis. Part 1. Physical and mineralogical methods. The Amer. Soci. of Agron., Madison, Wisco., USA.:361 -368.

Masoud, R. and S. Ghodratolah (2010). Water use efficiency of corn as affected by every other furrow irrigation and planting density. Islamic Azad Univ., Branch Khorramabad, Iran. World Appl. Sci. J. 11 (7): 826-829.

Merriam, J. L. and J. Keller (1978). Farm irrigation system evaluation: A guide for management. Utah State Univ. Agr. and Irri. Eng. Dep., Logan, Utaha.:202 -207

Oweis, T.; Hachum, A. and Pala, M. (2005). Faba bean productivity under rainfed and supplemental irrigation in northern Syria. Agric. Water Manage. 73:57-72.

Page, M. A. (1982). Methods of soil analysis. Part 2. Academic Press. Soil Sci. Soc. of Amer. Inc., N.Y., USA.:401 -409.

Saito, Y.; M. Hara; F. Kobayashi and T. D. Kawahara (2006). Laserinduced fluorescence (LIF) lidar for plant monitoring. Fac. of Eng., Shinshu Univ., 4-17-1 Wakasato, Nagano-city, Japan.:79 -84. 
Sander J. Zwart and Wim G. M. Bastiaanssen (2004) "Review of measured crop water productivity values for irrigated wheat, rice, cotton and maize." Agr. water manag. 69 (2): 115-133.

Schuerger, A. C.; G. A. Capelle; J.A. Di Benedetto; C. Mao; C. N. Thai; M. D. Evans; J. T. Richards; T. A. Blank and E. C. Stryjewski (2003). Comparison of two hyperspectral imaging and two laser-induced fluorescence instruments for the detection of zinc stress and chlorophyll concentration in bahia grass (Paspalum notatum Flugge.). Remote Sensing of Envi. 84: 572-588

Shawky, M. E. (1976). Micro and macro pore-space distribution in profiles of typical Egyptian soils and factors affecting. M.Sc. Fac. of Agri. Cairo Uni. Egypt.: 72-79.

Shock, C. (2007). Efficient irrigation scheduling, Univ. Malheur Exper. Sta., Oregon State, USA. Cited in: 45-51.

Waskom, R.M. (1994). Best management practices for irrigation management. Colorado St. Univ. Coop. Ext. Bull. No. XCM-173 :15.

Webber, H.A.; Madramootoo, C.A.; Bourgault, M.; Horst, M.G.; Stulina, G. and Smith, D.L. (2006). Water use efficiency of common bean and green gram grown using alternate furrow and deficit irrigation. Agric. Water Manage. 86(3): 259-268.

Yang, R. (2012). Estimation of maize evapotranspiration and yield under different deficit irrigation on a sandy farmland in Northwest China. African J. of Agr. Res. 7(33): 4698-4707.

$$
\text { الملخص العربيى : }
$$

المقتنات المائية لمحصول الذرة النيلى باستخدام شعاع الليزر

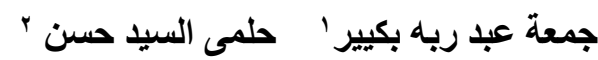

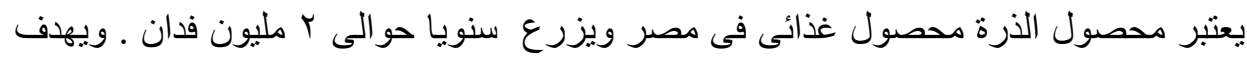

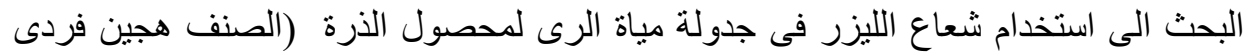
1) بهدف التحكم فى أدارة أنظمة مياة الرى لزيادة كفاءة الرئ أستخدام الري.

1 - أستاذ الهنذسة الزراعية ـ كلية الزراعة ـ جامعة القاهرة .

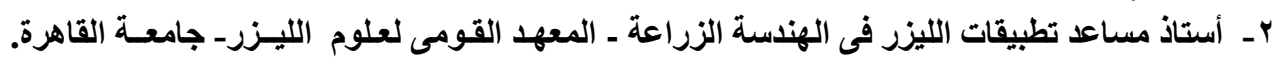


أجريت الدراسة الحقلية فى حقل التجارب بمزرعة كلية الزراعة - جامعة القاهرة اثناء العروة

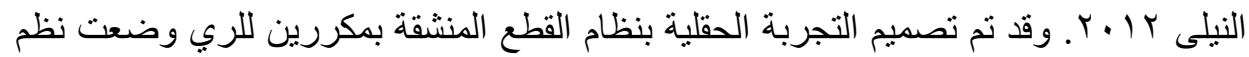

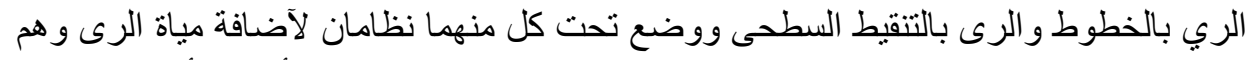

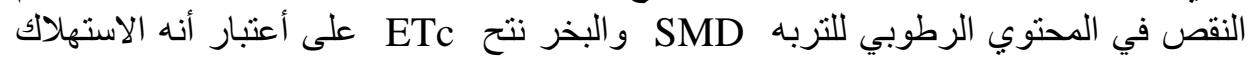

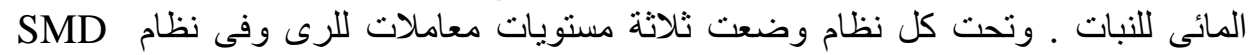

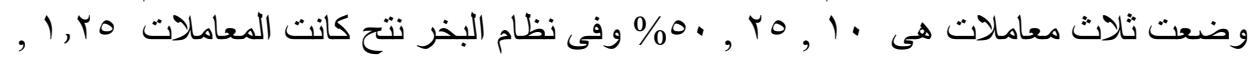

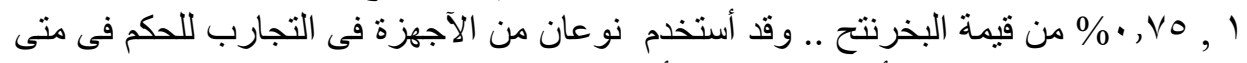

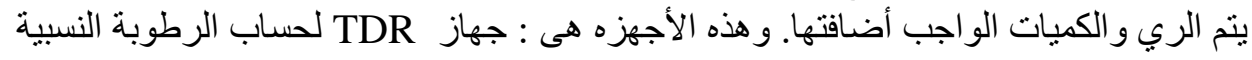

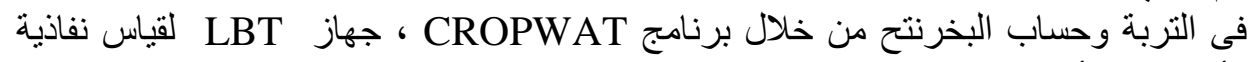

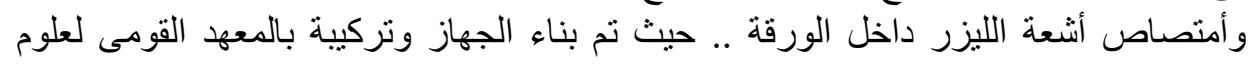

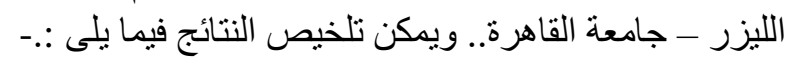

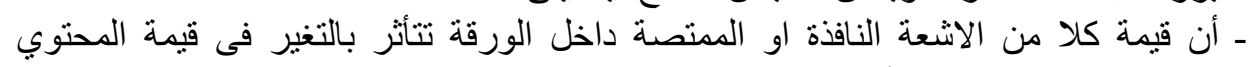

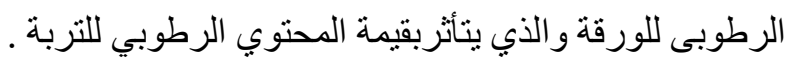

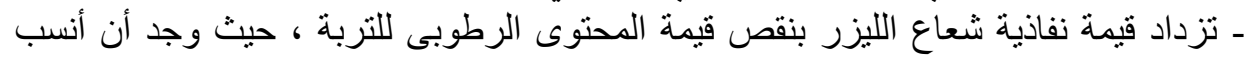



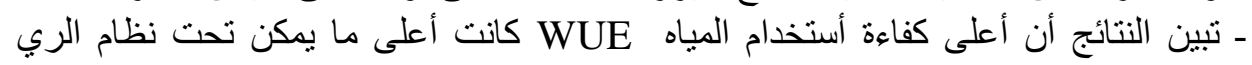

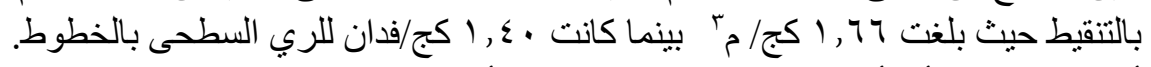

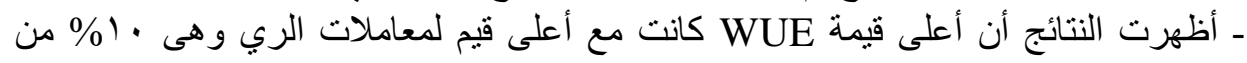

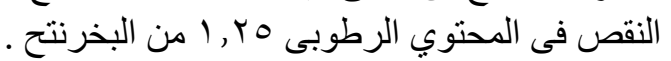

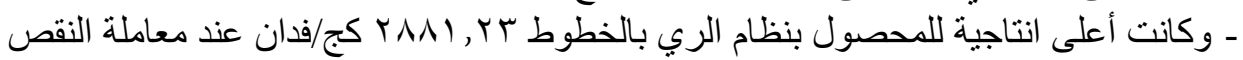

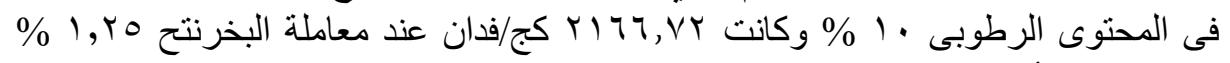

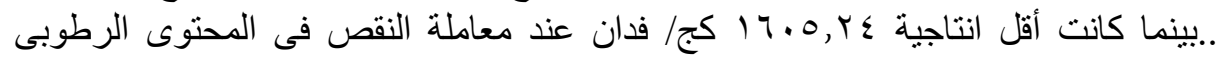

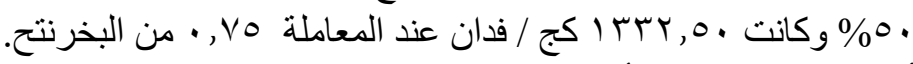

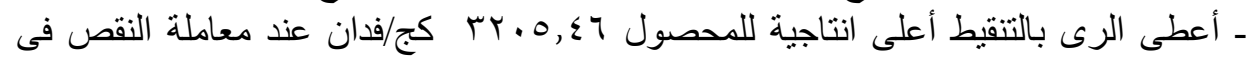

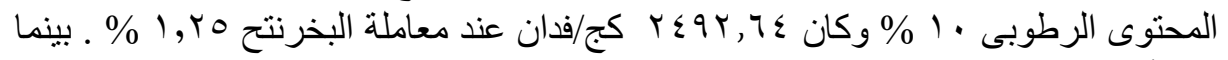

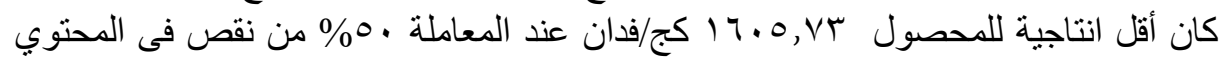

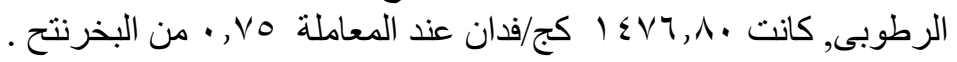

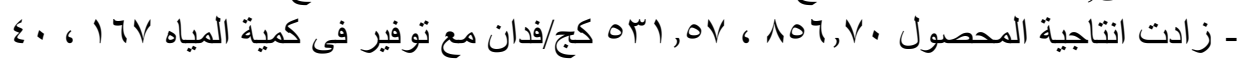

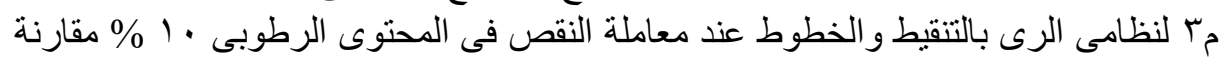

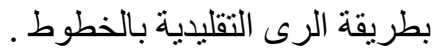

